$7^{\circ}$ Simposio Internacional de Investigación Multidisciplinaria / Ciencia y Tecnología 7th Internationalm Symposium on Multidisciplinary Research / Sciences and Technology

\title{
CT-20 SOA Software interactivo del aprendizaje de aritméticas básicas dirigido a estudiantes del quinto grado de primaria
}

\author{
SOA interactive software of basic arithmetic learning directed to elementary \\ fifth grade students \\ Wendi M. Santiago-León*, Freddy Solís-Montejo, Oscar Ovando-Bautista, Eloisa Mendoza-Vázquez \\ División Académica de Informática y Sistemas, Jalpa, Cunduacán, Tabasco, México.
}

*Autor al que se dirige la correspondencia: wendi.santiago@dais.ujat.mx

\section{Resumen}

T os software educativos constituyen una evidencia del impacto de la tecnología en la educación pues es la más Ureciente herramienta didáctica útil para el estudiante y profesor convirtiéndose en una alternativa válida que ofrece al usuario un ambiente propicio para la construcción del conocimiento. Se han implementado software educativos como apoyo al proceso de enseñanza-aprendizaje en nuestro país teniendo en cuenta los avances tecnológicos. Las escuelas de nuestro estado tienen la tecnología adecuada para la educación, pero no cuentan con las herramientas de software lo suficientemente atractivos para los alumnos. Por lo cual este documento presenta el desarrollo de un Software interactivo de enseñanza-aprendizaje de operaciones aritméticas para los niños de $5^{\circ}$ grado de primaria. El motivo principal por el cual se realizó este software, es para ayudar a los alumnos de este nivel a comprender y aprender dichas operaciones mencionadas en las clases por medio de los recursos informáticos. El desarrollo del software interactivo se plantea como una herramienta que proporciona un estilo de aprendizaje acorde a la realidad actual, motivando al alumno a comprender por sí mismo el tema de las operaciones aritméticas creativamente transformando el aprendizaje en un juego de exploración y aventura.

Palabras claves: software interactivo, primaria, operaciones aritméticas básicas

\begin{abstract}
$\mathrm{E}$ ducational software shows the impact of the new technologies applied to education, it represents the new eduCational tool for students and teachers, it gives a new alternative option to the user to build the construction of knowledge. In Mexico, several educational software have been applied in the school in order to help the learning teaching process. The elementary school in our state have the technology to teach the students but they do not have attractive software tools for students according to their needs. For this reason, this documents talks about the creation of an interactive software made specifically for learning the basic arithmetic operations for the $5^{\text {th }}$ grade of elementary school. It is a friendly and attractive tool for students.
\end{abstract}

Keywords: Educational software, elementary school, basic arithmetic operations 